\title{
SINGLE-PHASE GRID-CONNECTED PHOTOVOLTAIC SYSTEM WITH ACTIVE POWER LINE CONDITIONING
}

\author{
Sérgio A. Oliveira da Silva ${ }^{1}$, Leonardo B. G. Campanhol $^{2}$, Vinícius D. Bacon ${ }^{1}$, Leonardo P. Sampaio ${ }^{1}$ \\ Federal Technological University of Paraná - UTFPR-CP, Cornélio Procópio - PR, Brazil ${ }^{1}$ \\ Federal Technological University of Paraná - UTFPR-PG, Ponta Grossa - PR, Brazil ${ }^{2}$ \\ e-mail: augus@utfpr.edu.br'1, campanhol@utfpr.edu.br ${ }^{2}$,vinicius_vd@hotmail.com¹, sampaio@utfpr.edu.br ${ }^{1}$
}

\begin{abstract}
This paper deals with an alternative current reference generator algorithm proposition, which is employed to inject active power into the grid and, simultaneously, performs reactive power compensation and load harmonic current suppression in single-phase grid-connected photovoltaic (PV) systems. The PV system reference current is computed based on synchronous reference frame method, which operates in conjunction with the dc-bus controller. In addition, by adopting a proper strategy, it is proposed criteria for establishing the priority on the power compensation by the PV system, in order that the power rating of the gridconnected PWM converter is not exceeded. The Perturband-Observe maximum power point tracking technique is employed to generate the dc-bus voltage reference for extracting the maximum power from the photovoltaic array and, therefore, maximizing its efficiency. Both simulation and experimental results are presented to verify the static and dynamic behaviors of the grid-tied photovoltaic system, as well as evaluate its performance.

1
\end{abstract}

Keywords - Active Power Filter, Harmonic Suppression, Photovoltaic System, Power Quality, Reactive Power Compensation.

\section{INTRODUCTION}

In the last years, studies related to alternative and renewable energy sources have grown significantly [1], due to the increasing demand for electrical energy, and mainly because of the reduction of ecological and economic impacts. Hydropower, biomass, wind, sea and solar, arise among the several alternative and renewable energy sources. Considering this scenario, the solar energy can be considered the most useful of the available renewable energy sources.

After its conversion in electrical energy, by means of photovoltaic (PV) arrays, the solar energy can be injected into the utility grid by using proper energy conversion stages. Normally, for this purpose, it is performed by means of $\mathrm{dc} / \mathrm{dc}$ and dc/ac converters. The first is used to step-up the PV array voltage, while the second is used to connect the PV system to the utility grid [2]-[5]. In many PV systems, the $\mathrm{dc} / \mathrm{dc}$ conversion stage is suppressed, and the energy provided from the PV arrays is directly injected into the grid by using of dc/ac converter only [6]-[12].

On the other hand, the implementation of PV systems with filtering capabilities has been justified because the current

Manuscript received 08/04/2014; revised 03/07/2014; accepted for publication 14/03/2015, by recommendation of the Regular Section Editor Cassiano Rech. and/or voltage harmonic distortions have risen significantly in the power supply systems [10]-[15]. This problem has happened due to the increasing use of nonlinear loads, such as switching power supplies, inverters, rectifiers, among others, which are normally used in industrial, commercial and residential applications.

Since nonlinear loads have contributed for the generation of significant harmonic contents in the grid, they appear as the main responsible by changing the sinusoidal utility voltage characteristics, contributing for the power quality (PQ) degradation. Thus, when the harmonic currents interact with the utility impedance, result in voltage harmonic distortions that can affect the PQ of the consumers connected in the same electrical system point of common coupling. Additional effects can be seen through the excessive heating of transformers and electrical equipment, increasing noise in the audible frequency, and electromagnetic torque oscillations in electric motors [16].

Shunt active power filter (APF) arises as an alternative means to minimize some PQ problems. They have been used to eliminate or mitigate the effects on the power system caused by the circulation of harmonic currents created by nonlinear loads [17]-[19].

Considering single- and three-phase systems several gridtied photovoltaic systems with active filtering capability have been proposed in literature [10]-[13], using different strategies to perform the following purposes: i. injecting active power to the grid; ii. compensating of the load reactive power; and iii. suppressing of the load harmonic currents.

This paper proposes an alternative power-line conditioning algorithm implemented through the current reference generator (CRG), which is used to control the single-phase grid-tied photovoltaic and active power filter (PV-APF) system shown in Figure 1. The PV-APF system is connected to the utility grid by means of a current controlled full-bridge (1F-B) single-phase pulse width modulation (PWM) converter connected to the grid using a coupling inductor (L-filter) [11]-[13]. A simple algorithm is adopted to obtain the current reference, which is synthesized by the 1F-B converter. Thereby, the PV-APF current reference is obtained by using the method based on synchronous reference frame (SRF) operating in conjunction with the dcbus controller. In this case, the compensation current, composed of reactive and harmonic currents, is generated by the SRF-based algorithm, while the active current, obtained from the PV array, is generated by the dc-bus controller operating together with a phase-locked loop (PLL) system.

The PLL system is employed to obtain the synchronization between the PV-APF system and the utility grid [20], [21]. In addition, it is also used for generating the 
coordinates of the synchronous unit vector $\sin \left(\theta_{p l l}\right)$ and $\cos \left(\theta_{p l l}\right)$, which are used in the PV-APF current reference generator, such that $\theta_{p l l}$ must be equal to the estimated utility phase-angle $\theta$.

On the other hand, the power processed to perform the load reactive power compensation and the current harmonic suppression must be monitored such that the nominal power rating of the PWM converter is not exceeded. For this reason, it is proposed a calculation algorithm, which is used to limit the amount of power processed by the converter, in order that its rated current remains within the designed limits.

Some PV array models have been proposed in literature [23]-[26]. In this paper, the simulations involving the PV array is implemented by means of the equivalent electrical model proposed in [25], [26]. The PV-APF system is composed of ten modules connected in series resulting a maximum output voltage around $308 \mathrm{~V}$ in the dc-bus of the PV array, which operates at Maximum Power Point (MPP) under the Standard Test Conditions (STC). Thus, it is possible the direct connection between the PV array and the 1F-B converter dc-bus (Figure 1). Hence, the step-up stage is not needed [27], [28], increasing the overall system efficiency [29].

Mathematical analyses are presented, as well as simulation and experimental results are shown to evaluate both static and dynamic performance of the PV-APF system, validating the theoretical development.

\section{CHARACTERISTICS OF THE GRID-TIED PV-APF SYSTEM}

The complete PV-APF system is shown in Figure 1, where the PV arrangement is composed of ten panels connected in series providing maximum PV array output power around $2.4 \mathrm{~kW}$.

In the next subsections the following subjects are described: i. the equivalent PV model; ii. the implemented MPPT technique operating in conjunction with the dc-bus voltage controller; iii. the algorithm used for the current reference generation; iv. the PV-APF current controller; and v. the PLL system.

\section{A. PV Model}

In this work, it is adopted in the simulations, the solar cell equivalent electrical circuit presented in [23], [26], which is represented by a current source shown in Figure 2. Thus, the PV cell output current $i_{p v}$ is given by:

$$
i_{p v}=I_{p h}-I_{r}\left[e^{q \frac{V+i_{p v} R_{S}}{\eta k T}}-1\right]-\frac{V+i_{p v} R_{S}}{R_{p}}
$$

where $V$ is the output voltage at PV cell terminals; $I_{p h}$ and $I_{r}$ are the photocurrent and the reverse saturation currents, respectively; $R_{S}$ and $R_{p}$ are the series and shunt resistances, respectively; $q$ is the electron charge; $\eta$ is the ideality factor of the junction p-n; $k$ is the Boltzmann constant; $T$ represents the ambient temperature, in Kelvin; and $G$ represents the power density of the solar radiation.

The photocurrent current $I_{p h}$ and the reverse saturation current $I_{r}$ are given respectively by:

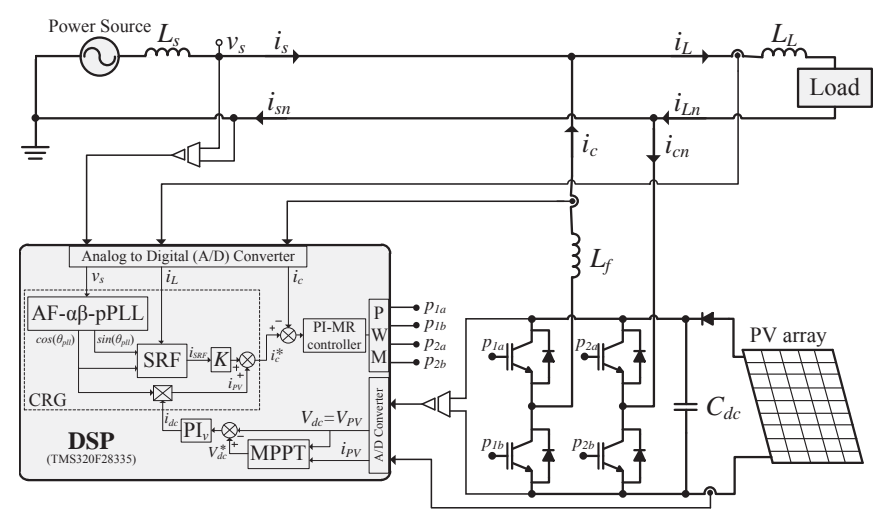

Fig. 1. Complete scheme of the single-phase grid-tied PV system.

$$
\begin{gathered}
I_{p h}=\left[I_{S C}+\alpha\left(T-T_{r}\right)\right] \frac{G}{1000} \\
I_{r}=I_{r r}\left(\frac{T}{T_{r}}\right)^{3} e^{\left[\frac{q E g}{\eta k}\left(\frac{1}{T_{r}}-\frac{1}{T}\right)\right]}
\end{gathered}
$$

where $T_{r}$ is the nominal temperature, in Kelvin $(298 \mathrm{~K})$; $I_{S C}$ is the short circuit current at STC $\left(T_{r}=25^{\circ} \mathrm{C}\right.$, and $G=$ $\left.1000 \mathrm{~W} / \mathrm{m}^{2}\right)$; $\alpha$ is the temperature coefficient; $I_{r r}$ is the diode reverse saturation current; and $E_{g}$ is the band gap energy $(1.1 \mathrm{eV})$.

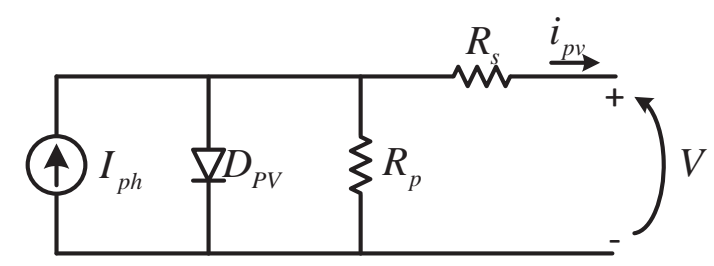

Fig. 2. Equivalent circuit of the photovoltaic cell.

The diode reverse saturation current and the PV array voltage $V_{P V}$ are given respectively by:

$$
\begin{gathered}
I_{r r}=\frac{I_{S C}-\frac{V_{O C}}{R p}}{e^{\frac{q V_{O C}}{\eta k T r}}-1} \\
V_{P V}=V N_{s} M_{S}
\end{gathered}
$$

where $V_{o c}$ is the open circuit voltage of the photovoltaic cells; $N_{S}$ is the number of photovoltaic cell; and $M_{S}$ is the number of the PV arrays connected in series.

In addition, the PV array open circuit voltage $V_{O C_{-} P V}$ is given by (6).

$$
V_{o c_{-} P V}=V_{o c} N_{S} M_{S}
$$

The PV cell current $\left(i_{p v}\right)$ given by (1) cannot be algebraically solved due to the nonlinear relationship between $i_{p v}$ and $V$. In this case, $i_{p v}$ is achieved by using the Newton-Raphson numeric method [30], [31].

Thus, for obtaining $i_{p v}$, which represents the behavior of the PV arrangement, it is used the calculation routine implemented in the PV model shown in Figure 3. The input parameters of the PV model are: output voltage $\left(V_{P V}\right)$, power solar radiation $(G)$, and ambient temperature $(T)$. These parameters are obtained in Standard Test Conditions (STC) [26]. 


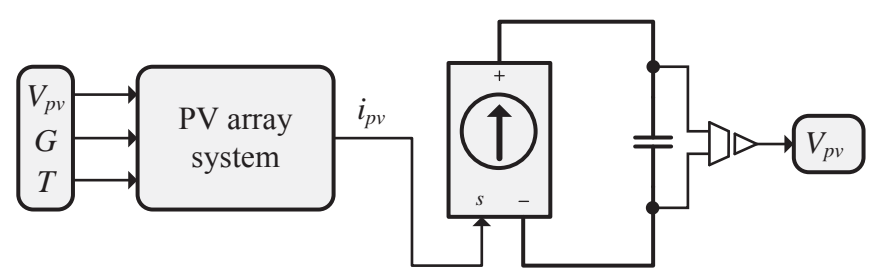

Fig. 3. Block diagram of the PV model.

\section{B. MPPT and dc-Bus Voltage Regulation}

In order to extract the maximum power from the PV array and, therefore, maximizing its efficiency, perturb-andobserve $(\mathrm{P} \& \mathrm{O})$ maximum power point tracking (MPPT) technique [22] is employed as shown in Figure 4. This MPPT algorithm operates, continuously, incrementing or decrementing both the output voltage and current of the PV array. It is performed a comparison between the PV power $\left(P_{p v}\right)$ and $\mathrm{PV}$ voltage $\left(V_{P V}\right)$, obtained in the current cycle, with the respective $P_{p v}$ and $V_{P V}$ quantities obtained in a previous cycle. If the $\mathrm{PV}$ array power increases, and its voltage also increase, the control increases the voltage reference $\left(V_{d c}^{*}\right)$. On the other hand, if the voltage decreases the voltage reference must decreases. An inverse logic is adopted when the PV array power decreases.

For extracting the maximum power of the PV array, the MPPT control operates incrementing or decrementing the voltage reference with a constant rate. As can be noted, the MPPT is employed to generate the PV array voltage reference $\left(V_{d c}^{*}\right)$, which is used as a reference voltage in the voltage loop control shown in Figure 7.

Moreover, a proper algorithm must be used to regulate the dc-bus voltage of the PV-APF system. The dc-bus voltage is regulated according to the power available in the PV array, i.e., when the environmental conditions, such as solar radiation and temperature are favorable, the dc-bus voltage reference $V_{d c}^{*}$ is set by means of the MPPT, such that $V_{d c}^{*}$ is greater than $210 \mathrm{~V}$. In this case, the power produced by the $\mathrm{PV}$ array is injected into the grid.

On the other hand, for unfavorable environmental condition, in which the voltage at maximum output power conditions $\left(V_{M P P}\right)$ in the $\mathrm{PV}$ array is not enough to guarantee the dc-bus voltage, the algorithm sets the dc-bus voltage reference to a constant value $\left(V_{d c}^{*}=210 \mathrm{~V}\right)$, in order to guarantee the system operation. The PV array reference voltage of $210 \mathrm{~V}$ was chosen in order to guarantee a proper operation of the converter, considering the following aspects: i. peak amplitude of the utility voltage $(180 \mathrm{~V}$ for nominal utility rms voltage); ii. losses in both switching devices and passive components (L-filter and dc-bus capacitor); and iii. dc-bus voltage dynamic when load transients occur.

During normal operating conditions of the PV-APF system, the $V_{M P P}$ is around $308 \mathrm{~V}\left(G=1000 \mathrm{~W} / \mathrm{m}^{2}, T=\right.$ $25^{\circ} \mathrm{C}$ ). On the other hand, taking into account a critical operation condition, such as $G=100 \mathrm{~W} / \mathrm{m}^{2}$ and $T=75^{\circ} \mathrm{C}$, the $V_{M P P}$ will be equal to $214 \mathrm{~V}$.

In addition, when partial shading occurs and involves up to three PV modules, the bypass diodes will reduce the operation voltage around to $216 \mathrm{~V}$. Therefore, the choice of $V_{d c}^{*}=210 \mathrm{~V}$ represents an acceptable voltage level, allowing an adequate operation of the PV-APF system. Thus, in this operation point, the MPPT algorithm remains operating with constant voltage and does not extract the maximum power available in the PV array. On the other hand, the PV-APF provides active energy to the grid and can also perform load harmonic current suppression and reactive power compensation.

Thereafter, when the PV array does not have enough power to guarantee the power supply for the dc-bus voltage, the algorithm maintains the dc-bus voltage control as constant voltage, in order to guarantee the active power filtering operation only. In this case, the dc-bus voltage is controlled by the energy provided from the grid, and the PVAPF system operates as a conventional shunt APF. Thus, the active energy consumed by the load is drained from the grid.

However, as can be noted, the active energy consumed by the load can be provided from both PV-APF system and utility grid, while the PV-APF system performs, continuously, the active filtering.

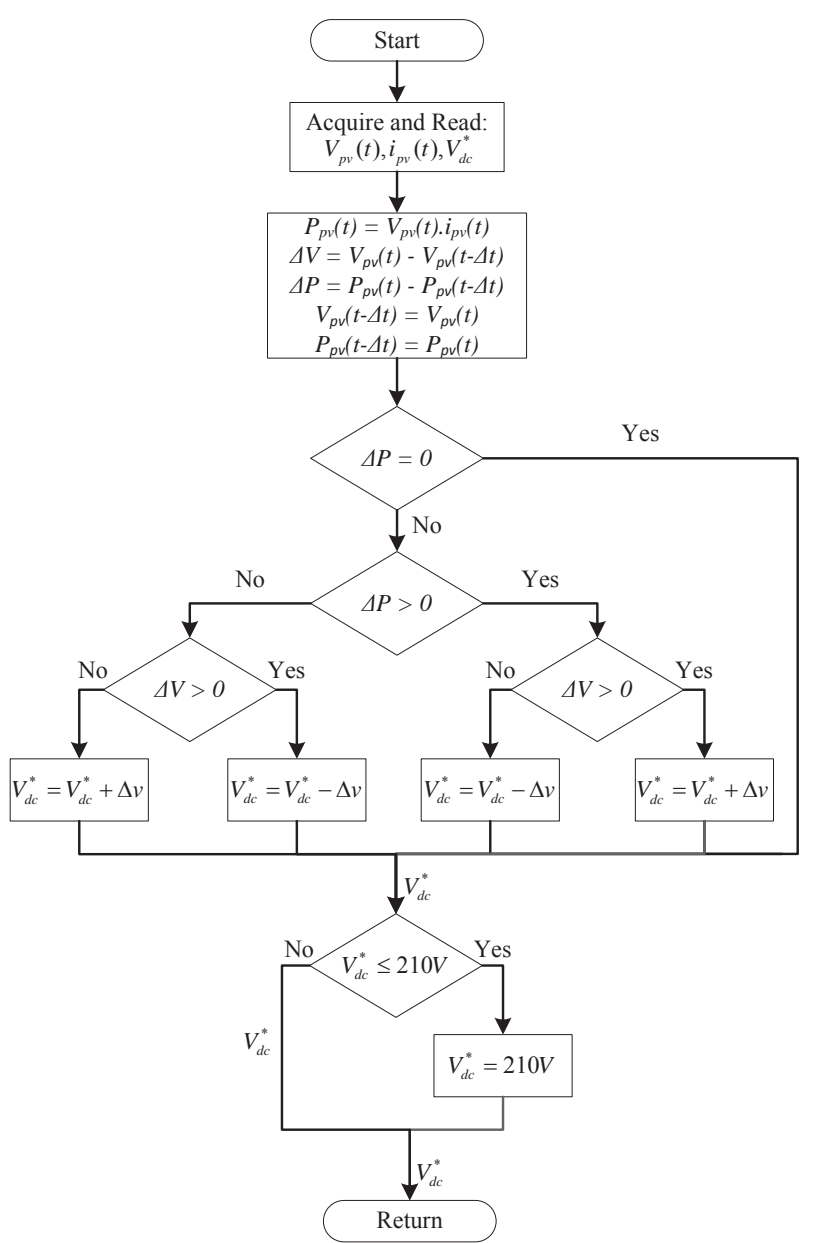

Fig. 4. Block diagram of $\mathrm{P} \& \mathrm{O}$ MPPT algorithm.

The voltage step size $(\Delta v)$ used in the $\mathrm{P} \& \mathrm{O}$ algorithm must be chosen to guarantee a good performance of the system. If $\Delta v$ is small, the state-steady error is reduced, however, when fast environment conditions changes occur, the algorithm can become less efficient. On the other hand, when $\Delta v$ reaches large values, the losses in steady-state increases due to the oscillations around the MPP [22], [32].

Thereby, by means of a computational searching, it was possible to obtain an adequate voltage step size, such that $\Delta v=1 \mathrm{~V}$. 
The $\mathrm{P} \& \mathrm{O}$ algorithm runs at constant sampling time interval $\left(T_{S_{M P P T}}\right)$. Similar to $\Delta v$, small values of $T_{S_{M P P T}}$ lead to fast transient when solar radiation changes occur, while for large $T_{S_{M P P T}}$ values the algorithm becomes slow, causing losses in the power extraction of the PV array [22], [32].

\section{Generation of the PV-APF Current Reference}

Several methods and theories have been proposed in order to generate the compensation current reference for shunt APF. In this paper, for this purpose, it was used an algorithm based on synchronous reference frame method. In the SRFbased algorithms, the fundamental terms of voltage and/or current of the $a b c$-phase stationary reference frame are transformed into continuous quantities into the $d q$ synchronous frame, in which they rotate at synchronous speed in relation to the voltage and current space vectors.

In the $d q$-axes, the harmonic contents of voltage and/or current can be represented by alternating quantities, which are superimposed to the continuous terms. Therefore, the fundamental components can be easily obtained by means of low-pass filters (LPFs). Phase-locked loop algorithms can be used to estimate the utility grid phase-angle, allowing the generation of the coordinates $\sin (\theta)$ and $\cos (\theta)$, that define the synchronous unit vector used in the SRF-based algorithms, where $\theta$ is the estimated phase-angle of the utility grid $\left(\theta=\theta_{p l l}\right)$.

The block diagram of the PV-APF current reference generator $(\mathrm{CRG})$ is shown in Figure 5. In this diagram is included the SRF-based algorithm that is employed to extract the harmonic components and the reactive fundamental component of the load current, represented by $i d_{h}$ and $i q=i q_{d c}+i q_{h}$ in the synchronous rotating frame. Thus, $i d_{h}$ and $i q_{h}$ represent the harmonic currents, and $i q_{d c}$ represents the reactive fundamental component of the load.

Since the SRF-based algorithm was conceived to be used in balanced three-phase systems, it is necessary to create a fictitious three-phase system to allow its application in single-phase systems [19]. Therefore, the load current is measured and it is considered the actual fictitious current $i_{\alpha}$ $\left(i_{L}=i_{\alpha}\right)$. Subsequently, $i_{\alpha}$ is phase-delayed in $\pi / 2$ radians, producing the fictitious $\beta$ coordinate $\left(i_{\beta}\right)$. Thereby, the new fictitious two-phase stationary reference frame ( $\alpha \beta$-axes) is represented by:

$$
\left[\begin{array}{l}
i_{\alpha} \\
i_{\beta}
\end{array}\right]=\left[\begin{array}{c}
i_{L}(\theta) \\
i_{L}(\theta-\pi / 2)
\end{array}\right]
$$

After that, the currents $i_{\alpha}$ and $i_{\beta}$ are transformed from the two-phase stationary reference frame into a two-phase synchronous rotating reference frame ( $d q$-axes).

Both direct (id) and quadrature $(i q)$ currents are obtained by means of $(8)$, where $\sin \left(\theta_{p l l}\right)$ and $\cos \left(\theta_{p l l}\right)$ are the coordinates of the synchronous unit vector obtained from the PLL system. The dc component $i d_{d c}$ (Figure 5) represents the fundamental active current of the load, which is extracted by using a $2^{\text {nd }}$ order LPF Butterworth filter.

$$
\left[\begin{array}{l}
i_{d} \\
i_{q}
\end{array}\right]=\left[\begin{array}{cc}
\cos \left(\theta_{p l l}\right) & \sin \left(\theta_{p l l}\right) \\
\sin \left(\theta_{p l l}\right) & -\cos \left(\theta_{p l l}\right)
\end{array}\right]\left[\begin{array}{c}
i_{\alpha} \\
i_{\beta}
\end{array}\right]
$$

The current generated by the SRF-based algorithm $i_{S R F}$ (Figure 5) is added to the sinusoidal PV current $i_{P V}$ represented by:

$$
i_{P V}=i_{d c} \cos \left(\theta_{p l l}\right)
$$

where $i_{d c}$ is obtained from the dc-bus voltage controller and represents the active power flow through the PV-APF system.

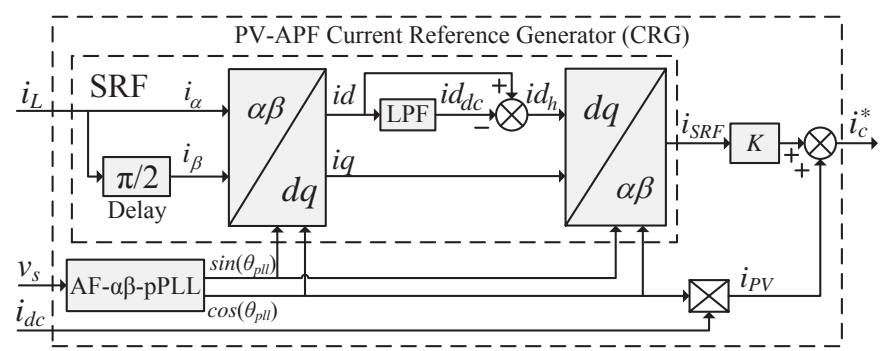

Fig. 5. Block diagram of the PV-APF current reference generator.

The quantity $i_{d c}$ determines if the PV-APF system absorbs active power from the grid or furnishes active power into the grid. Besides, the active power generated by the PV-array, $i_{d c}$ also represents the losses related to both the inductance filter $L_{f}$ and the switching devices. In other words, $i_{d c}$ controls the total active power demanded by the PV-APF system to regulate the dc-bus voltage.

The delay introduced into $i_{\alpha}$ to obtain the fictitious current $i_{\beta}$ must not interfere on the dynamic response of the current obtained from the CRG. This is achieved because during $1 / 4$ of the utility period $(\pi / 2 \mathrm{rad})$, the load current $\left(i_{L}=i_{\alpha}\right)$ is measured and stored in the DSP buffer. Thus, $i_{\beta}$ in fact represents the quadrature current of the fictitious twophase reference frame without any delay. In addition, if the utility frequency varies, the PLL system adjusts the time related to the $\pi / 2 \mathrm{rad}$ delay that could cause any problem.

Furthermore, it is known that both the LPF and the PLL dynamic responses can interfere on the dynamic response of the PV-APF system. On the other hand, these interferences are not able enough to affect the PV-APF performance.

The PV-APF current reference $i_{c}^{*}$ shown in Figure 5 is achieved as follows:

$$
i_{c}^{*}=i_{S R F} K+i_{P V}
$$

As can be noted, the constant $K$ that appears in (10) is used to control the amount of power processed by the PWM converter, in order that its rated current remains within the designed limits. This constant $K$ is calculated by:

$$
K=\frac{I_{S R F \max }}{I_{S R F}}=\frac{\sqrt{I_{i n v}^{2}-I_{P V}^{2}}}{I_{S R F}}=\frac{\sqrt{I_{i n v}^{2}-\left(i_{d c} / \sqrt{2}\right)^{2}}}{I_{S R F}}
$$

where $I_{i n v}$ is the nominal rms current of the VSI converter; $I_{P V}$ is the actual PV array rms active current $\left(i_{P V}\right)$ obtained from the dc-bus voltage controller; and $I_{S R F}$ is the actual rms current obtained from SRF algorithm $\left(i_{S R F}\right)$.

Thus, when $I_{S R F} \leq \sqrt{I_{i n v}^{2}-I_{P V}^{2}}, K=1$, otherwise, $K<1$ as obtained by (11), and, therefore, the amplitude of the current 
$i_{S R F}$ is reduced. Figure 6 presents the constant $K$, in function of the nominal rms SRF current $\left(I_{S R F}\right)$.

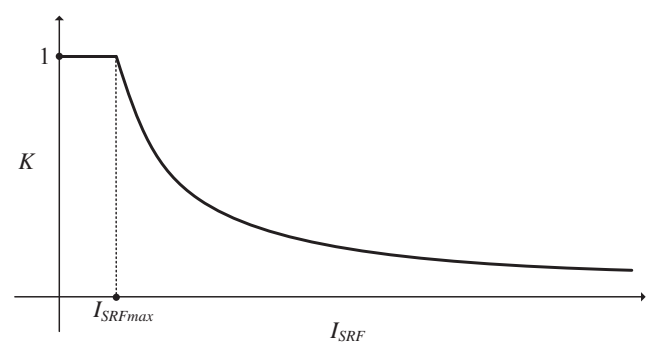

Fig. 6. Constant $K$ used to control the power flow through the PVAPF system.

\section{Current and dc-Bus Control Loops of the PV-APF System}

The block diagram of the current controller used to control the $1 \mathrm{~F}-\mathrm{B}$ converter is shown in Figure 7, considering that the current reference $i_{c}^{*}$ is achieved from the CRG presented in Figure 5. In addition, $L_{f}$ and $R_{L f}$ are, respectively, the inductance and the resistance of the L-filter connected to the grid, and $K_{P W M}$ represents the static gain of the PWM converter, which is calculated taking into account the peak value of the PWM triangular carrier [35].

As can be seen from (10), the compensating reference current $i_{c}^{*}$ is not a continuous quantity. Thus, this leads to non-null errors in steady-state when conventional PI controller is employed. Thereby, a Proportional-Integral Multi-Resonant (PI-MR) controller [33], [34] is used to control the current synthetized by the 1F-B converter. This controller provides an infinite open loop gain at the resonant frequency $\left(\omega_{o}\right)$, which can result zero steady-state error [33].

The transfer function of the PI-MR controller is given by:

$$
\begin{gathered}
G_{P I-M R}(\mathrm{~s})=k_{P i}+\frac{k_{I i}}{s}+\sum_{m=1}^{n} \frac{k_{m} s}{\left(s^{2}+\left(m \omega_{1}\right)^{2}\right)}= \\
=G_{P I}(s)+\sum_{m=1}^{n} G_{M R(m)}(s)
\end{gathered}
$$

where $k_{P i}$ and $k_{I i}$ represent, respectively, the proportional and integral gains of the current PI controller; $k_{m}$ represents the resonant gains at a specific resonant frequency, $\omega_{1}$ is the fundamental frequency, and $m=1,3,5, \ldots, n$. In this paper $n$ $=9$, meaning that the resonant terms are composed of the $1^{\text {st }}$, $3^{\text {rd }}, 5^{\text {th }}, 7^{\text {th }}$ and $9^{\text {th }}$ components. It is noted that the fundamental component $(m=1)$ is considered in (8), in order to compensate the load reactive component, as well as the active component injected into the grid, both at fundamental frequency.

In Figure 7 is also represented the dc-bus voltage controller. It is responsible to provide the signal $i_{d c}$ to the CRG (Figure 5), in order to determine the amplitude of the active current that is injected into the grid. Thereby, the dcbus control loop must present reduced bandwidth to avoid any distortions in reference current $\left(i_{c}^{*}\right)$.

When the PV-APF system is working as shunt-APF only, the dc-bus voltage is maintained constant by draining active current from the electric grid. This current compensates the losses in the PV-APF system keeping dc-bus voltage constant.

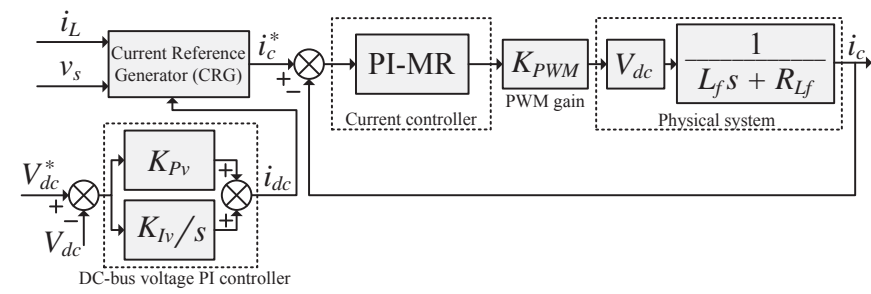

Fig. 7. Block diagram of the current control loop.

The proportional and integral dc-bus controller gains, $k_{P v}$ and $k_{I v}$, shown in Figure 7, are determined using modeling and design procedures presented in [19].

\section{E. PLL System}

The single-phase PLL system implemented in this paper is shown in Figure 8. It uses a non-autonomous adaptive filter (AF) operating in conjunction with the $\alpha \beta$-pPLL originating the AF- $\alpha \beta$-pPLL scheme [20], [21]. In [21] it is presented the design requirements and procedures used for determining the PLL PI controller gains involving its stability analysis. In addition, extensive experimental tests confirm the good performance when this PLL scheme is submitted to utility disturbances, such as voltage harmonics, voltage sags/swells, phase-angle jumps and frequency variations.

The AF- $\alpha \beta$-pPLL proportional $\left(k_{P p l l}\right)$ and integral $\left(k_{I p l l}\right)$ controller gains, as well as the AF gain $K_{c}=\mu / T_{s}$ are presented in Table II, where $T_{S}$ is the DSP sampling time, $\mu$ is the adaptation step time, and $A$ is the amplitude of the fundamental utility voltage, which is calculated based on the weights $w_{1}$ and $w_{2}$ of the AF, such that $A=\sqrt{w_{1}^{2}+w_{2}^{2}}$ [20].

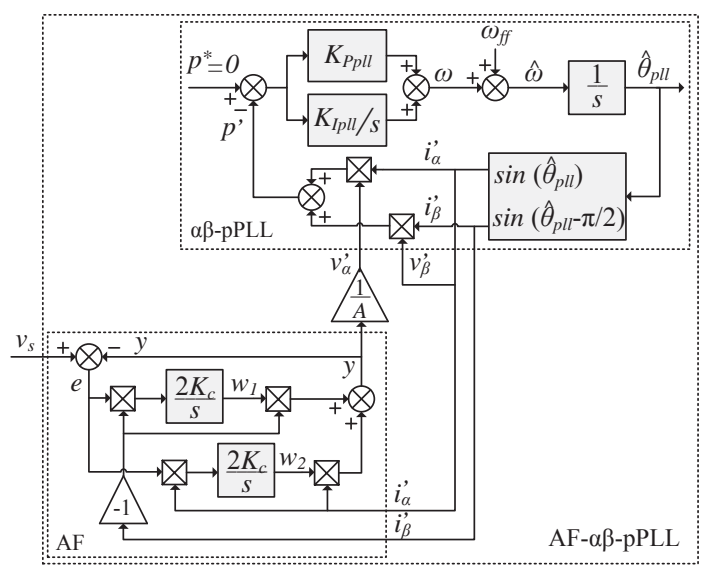

Fig. 8. Single-phase AF- $\alpha \beta$-pPLL scheme.

\section{IMPLEMENTATION OF THE PV-APF SYSTEM}

Figure 1 shows the complete scheme of the PV-APF system. As can be seen, the SRF and PLL algorithms, the MPPT technique, the current and dc-bus voltage controllers, as well as the 1F-B converter of the PV-APF system were tested by means of numerical simulation, using the MATLAB/Simulink tools, and by experimentation. In addition, in order to perform the simulation tests as close as possible of the real system, all parts of the system were discretized, including the algorithms, data acquisition signals and controllers. Besides, the acquisition delays, normally introduced by the anti-aliasing filter, were taken into account, 
as well as the dead-time of the switching devices. Table I summarizes the PV module parameters implemented in the simulations and experimentations, and Table II shows the parameters of the shunt-APF and the gains of the PI-MR, PI dc-bus, and PI PLL controllers. The procedure used for tuning all the PI controllers was based on the frequency response method via Bode diagrams [19]. This method can be employed when the phase margin and the $0 \mathrm{~dB}$ gain crossover frequency are used as design specifications. In addition, the multi-resonant controller gains $\left(k_{m}\right)$ presented in (12) are obtained in order to guarantee that each one of the multi-resonant crossover frequencies $\left(\omega_{\mathrm{cm}}\right)$, related to $G_{M R(m)}$, are equal to the adopted crossover frequency $\left(\omega_{c i}\right)$ used in the PI current controller specification design, such that $\omega_{c m}=\omega_{c i}$.

The PV-APF system was experimentally tested based on the Digital Signal Processor (DSP) TMS320F28335 (Texas Instruments), which was used to implement the MPPT technique (Figure 4), the current reference generator (Figure 5), and the PLL algorithm (Figure 7). As can be seen, the nonlinear load used in the tests is composed of a full-bridge diode rectifier followed by $\mathrm{RC}$ load. The switching frequency of the PWM converter was set at $20 \mathrm{kHz}$. The fullbridge converter employs two IGBT modules (SK40GB 123 Semikron) with their proper drivers. Three current sensors model LEM LA 100-P are used to measure the PV array, load and converter currents. The input ac voltage and the dcbus voltage (PV array voltage) are measured using two voltage sensors model LEM LV 25-P.

\section{A. Simulation Results}

Figure 9 shows the dynamic behavior of the PV-APF system taking into account three distinct operation modes (OPM), where the attenuation constant $K$, shown in Figure 6 , is used to control the amount of power processed by the PWM converter.

Details related to the transitions from the OPM 1 to 2 and from the OPM 2 to 3 are shown in Figures 9 (a) and (b), respectively, where are shown the utility voltage $\left(v_{s}\right)$, the utility current $\left(i_{s}\right)$, the compensation current synthesized by the $1 \mathrm{~F}-\mathrm{B}$ converter $\left(i_{c}\right)$ and the load current $\left(i_{L}\right)$.

Initially, as shown in Figure 9 (a), from 19.95 to $20 \mathrm{~s}$ only load active power injection is carried out, while the reactive power compensation and harmonic current suppression are not taken into account (OPM 1). After that, from 20 to $20.25 \mathrm{~s}$, both reactive power and harmonic currents are compensated in conjunction with the active power injection (OPM 2). Finally, as shown in Figure 9 (b), from 29.95 to $30 \mathrm{~s}$ the PV-APF system is operating in OPM 2. After that, from 30 to $30.25 \mathrm{~s}$, the load apparent power (VA) related to the reactive power and harmonic components of the load is increased, occasioning the attenuation of the reference compensation current $i_{c}^{*}(\mathrm{OPM} 3)$. In Figure 9 (c) and (d) the ideal PV available power $\left(P_{p v}^{*}\right)$, the power $\left(P_{p v}\right)$ extracted from the PV arrays, the attenuation constant $(K)$, the nominal rms current of the converter $I_{i n v}$, the rms current of the converter $I_{c}$, the dc-bus voltage reference $V_{d c}^{*}$ set by means of the MPPT technique, and the dc-bus voltage $V_{d c}$ are shown considering the three OPMs. It is verified that there is no transition time between the OPMs 1 and 2. On the other hand, the transition time between the OPMs 2 and 3 is around $200 \mathrm{~ms}$. This transition time occurs due to the time spent to calculate the constant $K$, which depends on the calculation of the $I_{P V}$ and $I_{S R F}$ rms currents.

As can be noted, the attenuation constant $(K)$ is forced to zero $(K=0)$ in OPM 1 , while in the OPM 2 it is equal to one $(K=1)$ because $I_{S R F} \leq \sqrt{I_{i n v}^{2}-I_{P V}^{2}}$. In the OPM 3, since $I_{S R F}>\sqrt{I_{i n v}^{2}-I_{P V}^{2}}, K$ is calculated according to (11) and its value is set between zero and one $(0<K<1)$ as described in section II-C. As can be noted, in OPM 3, the most part of the active energy provided from the PV array is consumed by the load.

\section{TABLE I}

Standard Test Conditions (STC) of the SolarWorld Sunmodule Plus SW 245 PV Array

\begin{tabular}{cl}
\hline Maximum PV power & $P_{\max }=245 \mathrm{~W}$ \\
\hline Maximum power point voltage & $V_{m p p}=30.8 \mathrm{~V}$ \\
\hline Maximum power point current & $I_{m p p}=7.96 \mathrm{~A}$ \\
\hline Open circuit voltage & $V_{o c}=37.5 \mathrm{~V}$ \\
\hline Short-circuit current & $I_{s c}=8.49 \mathrm{~A}$ \\
\hline
\end{tabular}

TABLE II

Parameters Adopted in the Simulation and Experimental Tests

\begin{tabular}{|c|c|}
\hline Nominal utility rms voltage & $V_{s}=127 \mathrm{~V}$ \\
\hline Nominal utility frequency & $f=60 \mathrm{~Hz}$ \\
\hline Full-bridge converter nominal power & $S_{i n \mathrm{v}}=2540 \mathrm{VA}$ \\
\hline $\begin{array}{l}\text { Nominal rms current of the full-bridge } \\
\text { converter }\end{array}$ & $I_{i n \mathrm{v}}=20 \mathrm{~A}$ \\
\hline Inductive filter & $L_{f}=1.5 \mathrm{mH}$ \\
\hline Inductive filter resistance & $R_{L f}=0.48 \Omega$ \\
\hline Load capacitance & $C=940 \mu \mathrm{F}$ \\
\hline Load resistance & $R=30 \Omega$ \\
\hline Nominal load apparent power & $S_{L}=1110 \mathrm{VA}$ \\
\hline Load active power & $P_{L}=870 \mathrm{~W}$ \\
\hline Load Displacement Power Factor & $\mathrm{DPF}=0.99$ \\
\hline Load Power Factor & $\mathrm{PF}=0.78$ \\
\hline Commutation inductance & $L_{L}=1.2 \mathrm{mH}$ \\
\hline MPP dc-bus voltage & $V_{d c}=308 \mathrm{~V}$ \\
\hline dc-bus capacitor & $C_{d c}=2115 \mu \mathrm{F}$ \\
\hline Switching frequency & $f_{s w}=20 \mathrm{kHz}$ \\
\hline Sampling frequency A/D converter & $f_{s}=60 \mathrm{kHz}$ \\
\hline PWM gain & $K_{P W M}=5.33 \times 10^{-4}$ \\
\hline Current PI-MR controller gains & $\begin{array}{c}k_{P i}=175.25 ; k_{I i}=29727 \\
k_{1}=15700 ; k_{3}=15627 \\
k_{5}=15482 ; k_{7}=15265 \\
k_{9}=14975\end{array}$ \\
\hline $\begin{array}{l}\text { Crossover frequency } \\
\text { (Current PI controller) }\end{array}$ & $\omega_{c i}=15708 \mathrm{rad} / \mathrm{s}$ \\
\hline $\begin{array}{c}\text { Phase-margin } \\
\text { (Current PI controller) }\end{array}$ & $P M_{i}=89.9^{\circ}$ \\
\hline dc-bus PI controller gains & $k_{P v}=0.0996 ; k_{I v}=0.0902$ \\
\hline $\begin{array}{l}\text { Crossover frequency } \\
\text { (dc-bus controller) }\end{array}$ & $\omega_{c v}=47.124 \mathrm{rad} / \mathrm{s}$ \\
\hline $\begin{array}{c}\text { Phase-margin } \\
\text { (dc-bus controller) }\end{array}$ & $P M_{v}=88.9^{\circ}$ \\
\hline PLL PI controller gains & $k_{P p l l}=424.3 ; k_{\text {Ipll }}=32234$ \\
\hline $\begin{array}{l}\text { Crossover frequency } \\
\text { (PLL PI controller) }\end{array}$ & $\omega_{c_{-} p l l}=430.874 \mathrm{rad} / \mathrm{s}$ \\
\hline $\begin{array}{c}\text { Phase-margin } \\
\text { (PLL PI controller) }\end{array}$ & $P M_{p l l}=80^{\circ}$ \\
\hline Adaptive filter gain & $K_{c}=420$ \\
\hline $\begin{array}{l}\text { Cut off frequency (SRF Controller) } \\
\text { ( } 2^{\text {nd }} \text { order LPF Butterworth filter) }\end{array}$ & $f_{c}=30 \mathrm{~Hz}$ \\
\hline P\&O voltage step size & $\Delta v=1 \mathrm{~V}$ \\
\hline P\&O sampling time & $T_{S_{M P P T}}=0.5 \mathrm{~s}$ \\
\hline
\end{tabular}




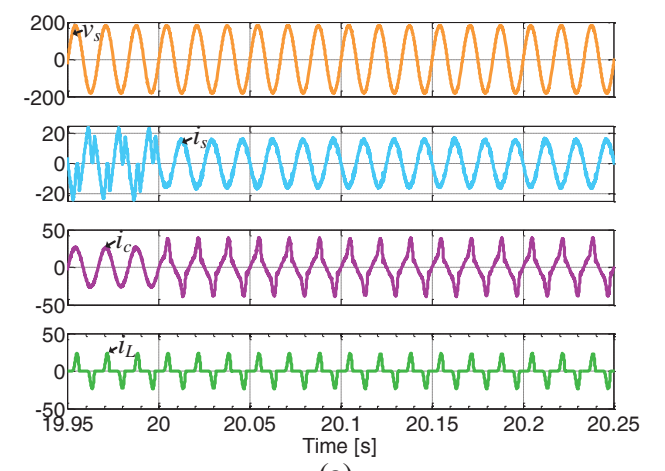

(a)
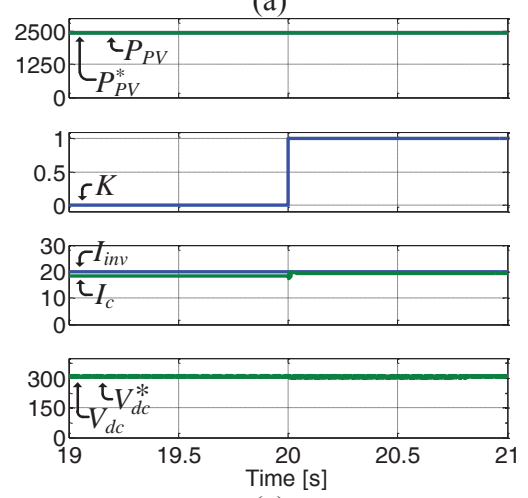

(c)

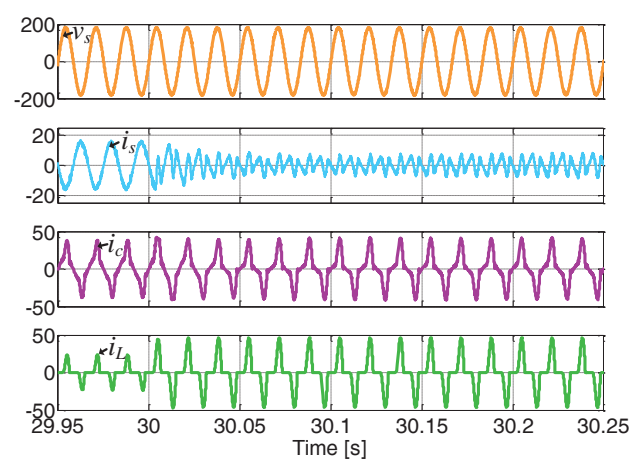

(b)

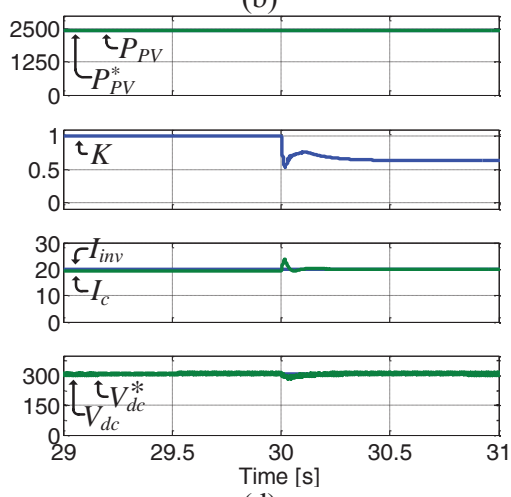

(d)

Fig. 9. Dynamic response for the OPMs 1, 2 and 3: (a) OPM $1(K=0)$ to OPM $2(K=1)$; (b) OPM $2(K=1)$ to OPM $3(0<K<1)$; (c) details related to transition from OPM 1 to OPM 2; (d) details related to transition from OPM 2 to OPM 3.
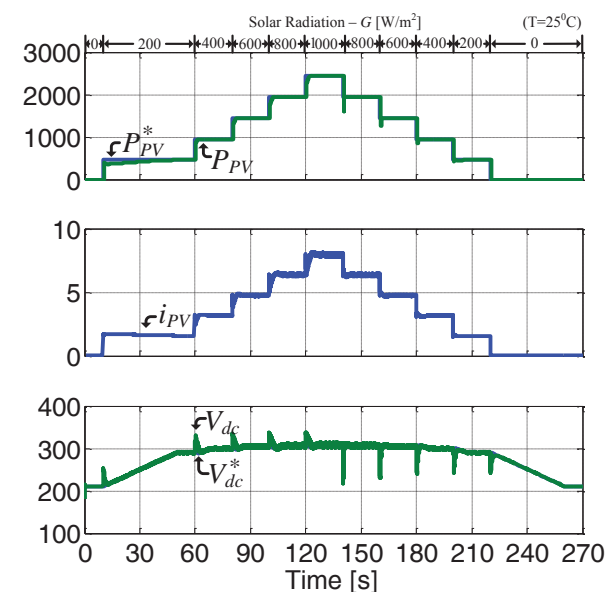

(a)
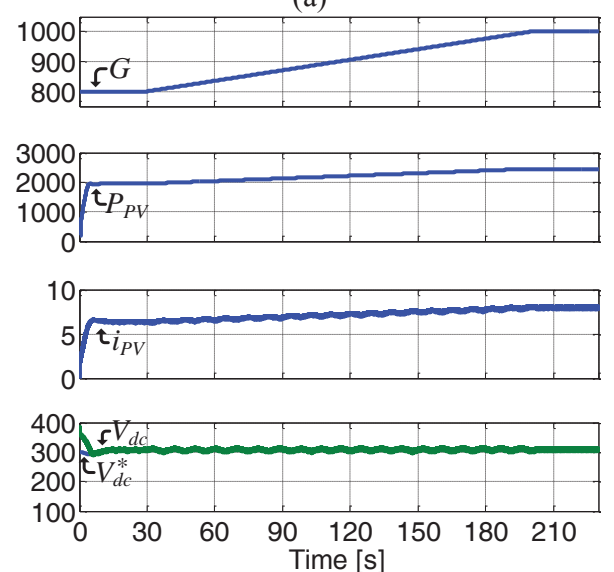

(c)
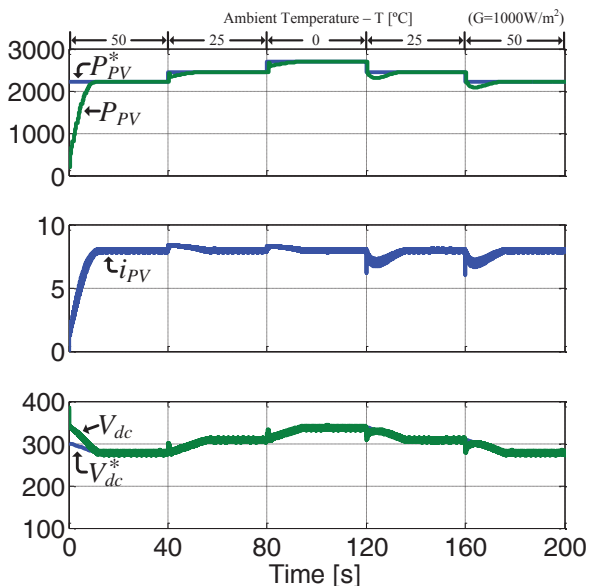

(b)
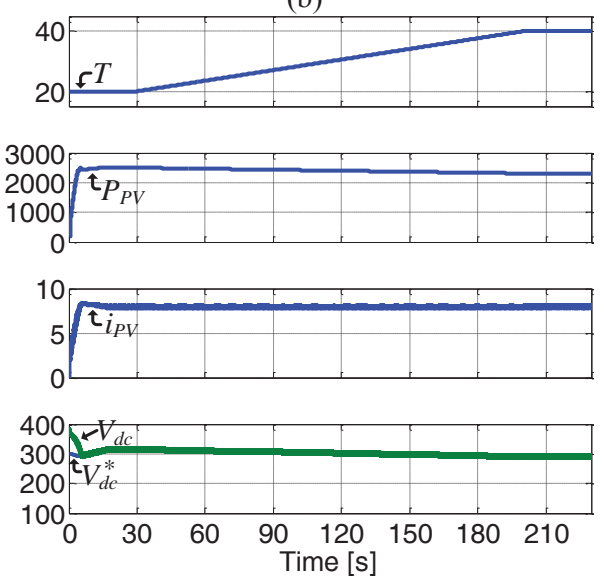

(d)

Fig. 10. MPPT dynamic during step and linear variations in the atmospheric conditions: (a) step variation in $G$; (b) step variation in $T$; (c) linear variation in $G$; (d) linear variation in $T$. 
Taking into account atmospheric condition changes (step and linear variations), the behavior of the PV-APF system is evaluated based on the quantities presented in Figure 10, where are shown the ideal available PV array power $\left(P_{p v}^{*}\right)$, the power extracted from the PV array $\left(P_{p v}\right)$, the PV array current $\left(i_{p v}\right)$, the dc-bus voltage reference set by the MPPT algorithm $\left(V_{d c}^{*}\right)$, the dc-bus voltage $\left(V_{d c}\right)$, the solar radiation $(G)$, and the ambient temperature $(T)$. In Figure 10 (a) and (b) results related to step variations in $G$ and $T$, respectively, are shown, while results related to linear variation are shown in Figure 10 (c) and (d). It can be noted that the MPP is tracked for all ranges of temperature and solar radiation. Besides, the amplitude of the dc-bus voltage is higher than $210 \mathrm{~V}$, as required in the design specifications.

\section{B. Experimental Results}

The static behavior of the PV-APF system is evaluated by means of the experimental results shown in Figure 11. It was considered four different cases related to the PV-APF system operation, which are described as follows: i. active power injection for the nonlinear load disconnected (case 1); ii. load reactive power compensation and harmonic current suppression (active power filtering), and utility grid active power injection (case 2); iii. active power filtering and both utility grid and load active power injection (case 3); and iv. active power filtering only (case 4). The following quantities are shown: voltage source $\left(v_{s}\right)$, source current $\left(i_{s}\right)$, compensation current $\left(i_{c}\right)$, and load current $\left(i_{L}\right)$.

In case 1 , all the active power produced by the PV array $\left(P_{p v}\right)$ is injected into the grid, because the load is disconnected. As can be noted in Figure 11 (a), the sinusoidal source current $i_{S}$ is in opposite phase with the utility voltage $v_{s}$; in case $2, P_{p v}$ is higher than the load active power $P_{L}$.

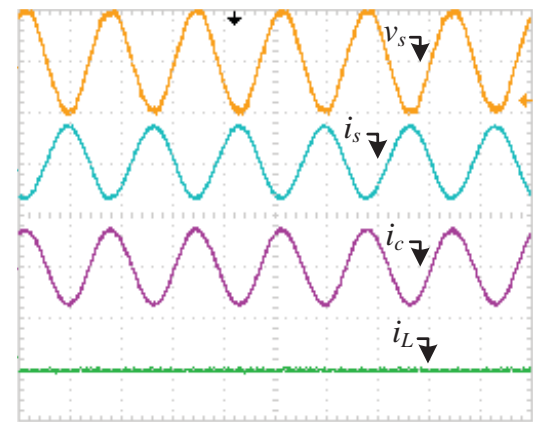

(a)

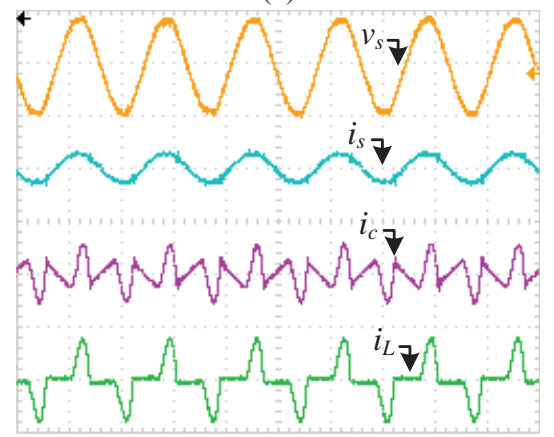

(c)
Thus, $P_{p v}$ is provided to both utility grid and the load, as can be seen in Figure 11 (b); in case 3, $P_{p v}$ is lower than $P_{L}$. In this case, $P_{p v}$ is totally provided to the load as shown in Figure 11 (c); and finally, Figure 11 (d) presents the results for the case 4 , where $P_{p v}$ is null. In this case, the PV-APF system performs the active power filtering only. It is verified that the source current is in phase with utility voltage.

Table III presents the total harmonic distortion (THD) related to the compensated source current $i_{s}$ considering the four operation modes of the PV-APF system. As can be observed, the THD of the source current was reduced in all presented cases $(1,2,3$, and 4$)$, mainly in the case $1\left(P_{p v}>0\right.$ and $P_{L}=0$ ), where the PV-APF system is only injecting active power into the grid $\left(T H D_{i_{S}}<5 \%\right)$ [36].

The dynamic behavior of the PV-APF system is evaluated by means of the experimental results shown in Figure 12. Figure $12(a)$ shows the MPP power $\left(P_{p v}\right)$ extracted from the PV array, the PV array current $i_{p v}$, and the dc-bus voltage $V_{d c}$, when a PV-array disconnection occurs at $0.7 \mathrm{~s}$. As can be noted, from 0 to $0.7 \mathrm{~s}$, the dc-bus voltage reference $V_{d c}^{*}$ is set by means of the MPPT-P\&O algorithm. After that, $P_{p v}$ and $i_{p v}$ fall to zero and the PV-APF system remains operating as APF and the dc-bus is set at $210 \mathrm{~V}$.

Figure 12 (b) and (c) shows the dynamic behavior of the PV-APF system when the nonlinear load step is suddenly applied. All the time, the PV-APF system shares the active energy produced by the PV array between the utility grid and the load. After the transient, it can be observed that the peak amplitude of the PV-APF system $\left(i_{c}\right)$ increases and the source current $\left(i_{s}\right)$ decreases, once the load current was increased. In this case, it is noted that the additional energy absorbed by the load was provided by the PV-APF system.

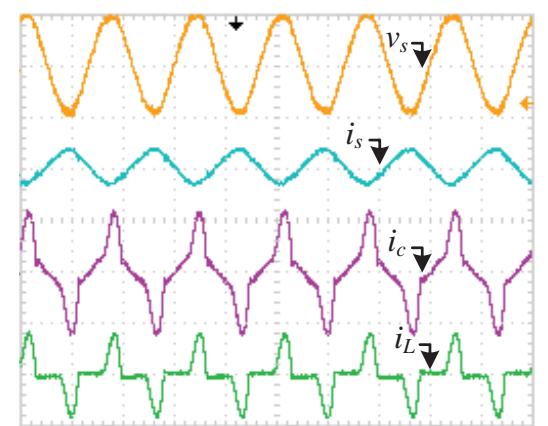

(b)

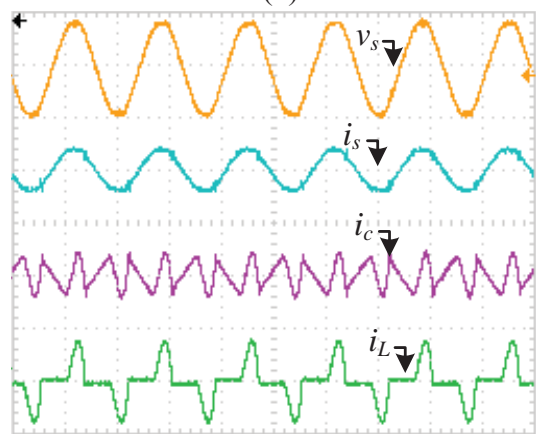

(d)

Fig. 11. Utility voltage $v_{S}(200 \mathrm{~V} / \mathrm{div}, 10 \mathrm{~ms} / \mathrm{div})$ and currents $i_{S}, i_{c}$, and $i_{L}(30 \mathrm{~A} / \mathrm{div}, 10 \mathrm{~ms} / \mathrm{div})$ for the PV-APF system: (a) case 1 $\left(P_{p v}=2000 \mathrm{~W} ; \quad P_{S}=-1820 \mathrm{~W}\right.$ and $\left.P_{L}=0 \mathrm{~W}\right) ;(\mathrm{b})$ case $2\left(P_{p v}=2000 \mathrm{~W} ; P_{S}=-1030 \mathrm{~W}\right.$ and $\left.P_{L}=870 \mathrm{~W}\right) ;(\mathrm{c})$ case 3 $\left(P_{p v}=300 \mathrm{~W} ; P_{S}=690 \mathrm{~W}\right.$ and $\left.P_{L}=870 \mathrm{~W}\right)$; and $(\mathrm{d})$ case $4\left(P_{p v}=0 \mathrm{~W} ; P_{S}=980 \mathrm{~W}\right.$ and $\left.P_{L}=870 \mathrm{~W}\right)$. 


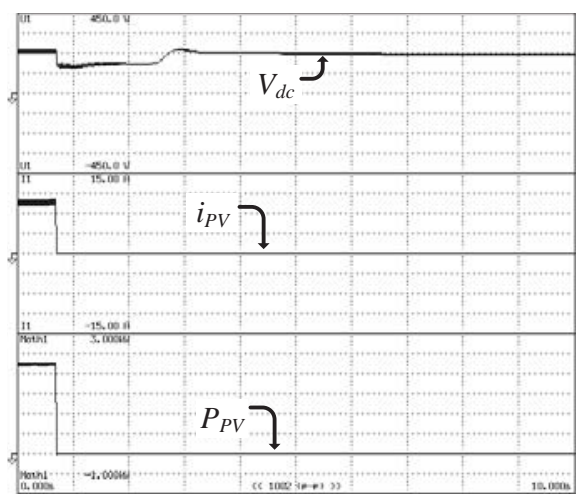

(a)

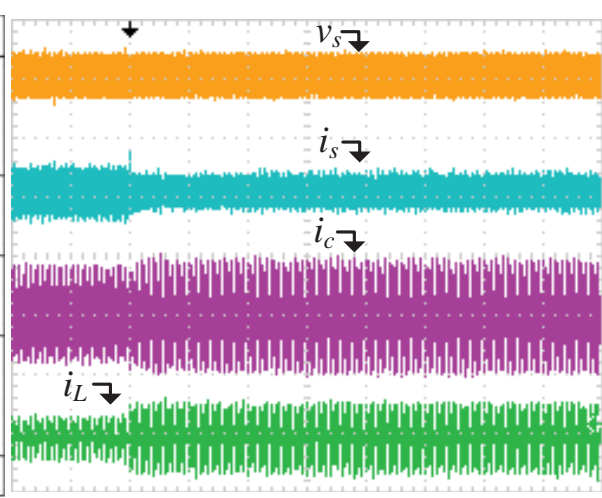

(b)

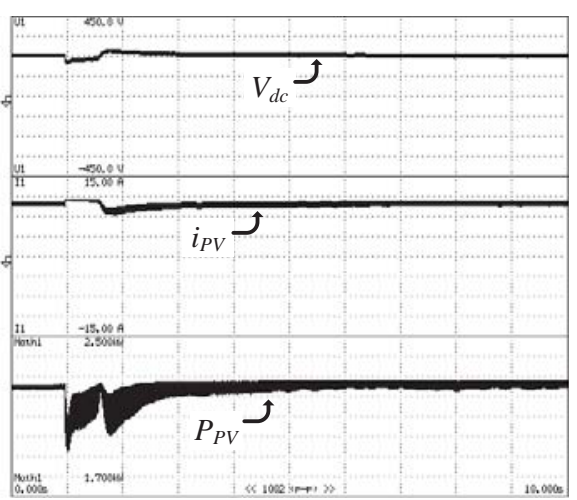

(c)

Fig. 12. PV-APF system dynamic responses ( $1 \mathrm{~s} /$ div): (a) PV array quantities, $i_{p v}(3.75 \mathrm{~A} / \mathrm{div}), P_{p v}(500 \mathrm{~W} / \mathrm{div})$ and $V_{d c}(112.5 \mathrm{~V} / \mathrm{div})$ for $\mathrm{PV}$ array disconnection; (b) utility voltage $v_{S}(500 \mathrm{~V} / \mathrm{div})$, currents $i_{s}, \quad i_{c}$, and $i_{L} \quad(40$ A/div $)$ for load step; (c) PV array quantities: $V_{d c}(112.5 \mathrm{~V} / \mathrm{div}), i_{p v}(3.75 \mathrm{~A} / \mathrm{div})$, and $P_{p v}(100 \mathrm{~W} / \mathrm{div})$ for load step.

TABLE III

THD of the Source and Load Currents for the Load Composed of a Full-Bridge Diode Rectifier Followed by RC Load (Experimental Results)

\begin{tabular}{c|cc}
\hline Cases 1, 2, 3 and 4. & \multicolumn{2}{|c}{$(\mathrm{THD} \%)$} \\
\cline { 2 - 3 }$i_{L}$ & 1.8 \\
\hline $\begin{array}{c}\text { 1. Active power injection, without nonlinear load } \\
\text { connected }\left(P_{p v}>0 \text { and } P_{L}=0\right)\end{array}$ & --- & 7.3 \\
\hline $\begin{array}{c}\text { 2. Active power injection with reactive and harmonic } \\
\text { compensation }\left(P_{p v}>P_{L}\right)\end{array}$ & 60 & 8.0 \\
\hline $\begin{array}{c}\text { 3. Active power injection with reactive and harmonic } \\
\text { compensation }\left(P_{p v}<P_{L}\right)\end{array}$ & 60 & 5.9 \\
\hline $\begin{array}{c}\text { 4. Reactive and harmonic compensation, with } \\
\text { nonlinear load connected }\left(P_{p v}=0\right)\end{array}$ & 60 & \\
\hline
\end{tabular}

\section{CONCLUSION}

This work presented a single-phase grid-tied PV system implementation with active power line filtering capability. An alternative current reference generator algorithm was proposed to perform active power injection into the grid, as well as load harmonic suppression and reactive power compensation. The PV-APF system was connected to the grid by means of a $1 \mathrm{~F}-\mathrm{B}$ converter, while the $\mathrm{PV}$ array was connected to the dc-bus without the step-up dc/dc converter use. Thus, the MPPT-P\&O technique acted directly on the 1F-B converter. In addition, it was proposed a calculation algorithm, used to limit the amount of the power processed by the $1 \mathrm{~F}-\mathrm{B}$ converter, when the PV-APF is injecting power into the grid and, simultaneously, operating as APF.

By means of simulation and experimental results, it was verified the static and dynamic behaviors of the PV-APF system, where good performance and effectiveness were achieved.

\section{REFERENCES}

[1] M. A. G. Brito, L. P. Sampaio, L. Galotto Junior, C. A. Canesin, "Research on Photovoltaics: Review, Trends and Perspectives", in Proc. of COBEP, pp. 531-537, 2011.

[2] S. B. Kjaer, J. K. Pedersen, F. Blaabjerg, "A Review of Single-Phase Grid-Connected Inverters for Photovoltaic Modules", IEEE Transactions on Industry Applications, vol. 41, no. 5, pp. 1292-1306, September/October 2005.
[3] M. F. Schonardie, R. F. Coelho, D. C. Martins, "Active and Reactive Power Control in a Three-Phase GridConnected PV Power System Using dq0 Transformation", Eletrônica de Potência, vol. 18, no. 4, pp. 1180-1187, September/November 2013.

[4] N. Altin, S. Ozdemir, "Three-Phase Three-Level Grid Interactive Inverter with Fuzzy Logic Based Maximum Power Point Tracking Controller", Energy Conversion and Management Journal, vol. 69, pp. 17-26, May 2013.

[5] R. G. Walker, C. P. Sernia, "Cascaded DC-DC Converter Connection of Photovoltaic Modules", IEEE Transactions on Power Electronics, vol. 19, no. 4, pp. 1130-1139, July 2004.

[6] S. Jain, V. Agarwal, "A Single-Stage Grid Connected Inverter Topology for Solar PV Systems with Maximum Power Point Tracking", IEEE Transactions on Power Electronics, vol. 22, no. 5, pp. 1928-1940, Sept. 2007.

[7] T.-F. Wu, C.-H. Chang, L-C. Lin, C.-L. Kuo, "Power Loss Comparison of Single- and Two-Stage GridConnected Photovoltaic Systems", IEEE Transactions on Energy Conversion, vol. 26, no. 2, pp. 707-715, June 2011.

[8] Y. Zhou, W. Huang, P. Zhao, J. Zhao, "A Transformerless Grid-Connected Photovoltaic System Based on the Coupled Inductor Single-Stage Boost Three-Phase Inverter", IEEE Transactions on Power Electronics, vol. 29, no. 3, pp. 1041-1046, March 2014.

[9] Y. Yang, F. Blaabjerg, "Low-Voltage Ride-Through Capability of a Single-Stage Single-Phase Photovoltaic System Connected to the Low-Voltage Grid", International Journal of Photoenergy, vol. 2013, pp. 1-9, 2013.

[10] A. V. Sant, V. Khadkikar, W. Xiao, H. Zeineldin, A. AlHinai, "Adaptive Control of Grid Connected Photovoltaic Inverter for Maximum VA Utilization”, in Proc. of IEEE Industrial Electronics Conference, pp. 388-393, 2013.

[11] T.-Fu Wu, H.-S. Nien, C.-L. Shen, T.-M. Chen, "A Single-Phase Inverter System for PV Power Injection and Active Power Filtering with Nonlinear Inductor Consideration", IEEE Transactions on Industry Applications, vol. 41, no. 4, pp. 1292-1306, July/August, 2005. 
[12] R. D. Patidar, S. P. Singh, D. K. Khatod, "Single-Phase Single-Stage Grid-Interactive Photovoltaic System with Active Filter Functions", in Proc. of IEEE Power and Energy Society General Meeting, pp. 1-7, 2010.

[13] K. C. A. Souza, W. M. Santos, D. C. Martins, "Optimization of the Magnetic Core Volume in a SinglePhase Grid-Connected PV System with Active and Reactive Power Control", Eletrônica de Potência, vol. 18, no. 4, pp. 1224-1234, September/November 2013.

[14] S. Sladić, S. Skok, D. Nedeljković, "Efficiency Considerations and Application Limits of Single-Phase Active Power Filter with Converters for Photoenergy Applications", International Journal of Photoenergy, vol. 2011, pp. 1-8, 2011.

[15] C. S. Postiglione, A. L. Fuerback, C. B. Nascimento, D. C. Martins, A. J. Perin, "AC-DC Serial-Interleaved Boost Converter Applied in a Single-Stage PFC", Eletrônica de Potência, vol. 18, no. 4, pp. 1170-1179, September/November 2013.

[16] R. C. Dugan, M. F. McGranaghan, S. Santoso, H. W. Beaty, Electrical Power Systems Quality, McGraw-Hill, Third Edition, New York, USA, 2012.

[17] M. Angulo, D. A. Ruiz-Caballero, J. Lago, M. L. Heldwein, S. A. Mussa, "Active Power Filter Control Strategy with Implicit Closed-Loop Current Control and Resonant Controller", IEEE Transactions on Industrial Electronics, vol. 60, no. 7, pp. 2721-2730, July 2013.

[18] G. Buticchi, L. Consolini, E. Lorenzani, “Active Filter for the Removal of the DC Current Component for Single-Phase Power Lines", IEEE Transactions on Power Electronics, vol. 60, no. 10, pp. 4403-4414, October 2013

[19] B. A. Angélico, L. B. G. Campanhol, S. A. O. Silva, "PI/PID Tuning Procedure of a Single-Phase Shunt Active Power Filter Using Bode Diagram", IET Power Electronics, vol. 7, no. 10, pp. 2647-2659, October 2014.

[20] S. A. O. Silva, V. D. Bacon, L. B. G. Campanhol, B. A. Angelico, "An Adaptive Phase-Locked Loop Algorithm for Single-Phase Utility Connected System," in Proc. of $15^{\text {th }}$ European Conference on Power Electronics and Applications (EPE), pp. 1-10, 2013.

[21] V. D. Bacon, S. A. O. da Silva, L. B. G. Campanhol, B. A. Angélico, "Analysis and Performance Evaluation of a Single-Phase Phase-Locked Loop Algorithm Using A Non-Autonomous Adaptive Filter", IET Power Electronics, vol. 7, no. 8, pp. 2081-2092, August 2014.

[22] M. A. G. de Brito, L. P. Sampaio, L. Galotto Jr., C. A. Canesin, "Evaluation of the Main MPPT Techniques for Photovoltaic Applications", IEEE Transactions on Industrial Electronics, vol. 60, no. 3, pp. 1156-1167, March 2013.

[23] M. M. Casaro, D. C. Martins, "Modelo de Arranjo Fotovoltaico Destinado a Análises em Eletrônica de Potência via Simulação", Eletrônica de Potência, vol. 13, no. 3, pp. 141-146, Agosto 2008.

[24] N. Pandiarajan, R. Ramaprabha, R. Muthu, “Application of Circuit Model for Photovoltaic Energy Conversion System", International Journal of Photoenergy, vol. 2012, pp. 1-14, 2012.
[25] J. A. Gow, C. D. Manning, "Development of a Photovoltaic Array Model for Use in Power-Electronics Simulation Studies", IEE Proceedings Electric Power Applications, vol. 146, no. 2, pp. 193-200, March 1999.

[26] A. C. M. Soares, E. Vieira, M. M. Casaro, "Simulation of a Photovoltaic Model Using Bisection Method", In Proc. of COBEP, pp. 807-811, 2011.

[27] S.-Y. Tseng, C-T. Tsai, "Photovoltaic Power System with an Interleaving Boost Converter for Battery Charger Applications", International Journal of Photoenergy, vol. 2012, pp. 1-15, 2012.

[28] K. I. Hwu, W. C. Tu, C. R. Wang, "Photovoltaic Energy Conversion System Constructed by High Step-Up Converter with Hybrid Maximum Power Point Tracking", International Journal of Photoenergy, vol. 2013, pp. 1-9, 2013.

[29] M. C. Cavalcanti, G. M. S. Azevedo, B. A. Amaral, K. C. de Oliveira, F. A. S. Neves, Z. D. Lins, "Efficiency Evaluation in Grid Connected Photovoltaic Energy Convertion Systems," in Proc. of $36^{\text {th }}$ Power Electronics Specialists Conference (PESC), pp. 269-275, 2005.

[30] A. Greenbaum, T. P. Chartier, Numerical Methods: Design, Analysis, and Computer Implementation of Algorithms, Princeton University Press, USA, 2012.

[31] J. D. Faires, R. L. Burden, Numerical Methods, Cengage Learning, USA, 2012.

[32] N. Femia, G. Petrone, G. Spagnuolo, M. Vitelli, "Optimization of Perturb and Observe Maximum Power Point Tracking Method", IEEE Transactions on Power Electronics, vol. 20, no. 4, pp. 963-973, July 2005.

[33] S. Fukuda, T. Yoda, "A Novel Current-Tracking Method for Active Filters Based on a Sinusoidal Internal Model", IEEE Transactions on Industry Applications, vol. 37, no. 3, pp. 888-895, May/June 2001.

[34] V.-T. Phan, H-H. Lee, "Control Strategy for Harmonic Elimination in Stand-Alone DFIG Applications with Nonlinear Loads", IEEE Transactions on Power Electronics, vol. 26, no. 9, pp. 2662-2675, Sept. 2011.

[35] S. Buso, P. Mattavelli, Digital Control in Power Electronics, Morgan \& Claypool Publishers, USA, 2006.

[36] IEEE Recommended Practice for Utility Interface of Photovoltaic (PV) Systems, IEEE Std. 929-2000, 2000.

\section{BIOGRAPHIES}

Sérgio Augusto Oliveira da Silva was born in Joaquim Távora, Brazil, in 1964. He received the B. S. and M. S. degrees in electrical engineering from Federal University of Santa Catarina (UFSC), Florianopolis, SC, Brazil, in 1987 and 1989, respectively. He received Ph.D. degree from Federal University of Minas Gerais (UFMG), Belo Horizonte, MG, Brazil, in 2001. Since 1993, he has been with the Electrical Engineering Department of Federal Technological University of Paraná (UTFPR-CP), Cornélio Procópio, PR, Brazil, where he is currently Professor of Electrical Engineering. His present research involves power electronics applications, UPS systems, active power filters, photovoltaic systems and control systems. He is member of Brazilian Power Electronics Society and IEEE. 
Leonardo Bruno Garcia Campanhol was born in Rolândia, Brazil, in 1986. He received the B. S. degree in industrial automation technology, and the post-graduate degree in automation and control of industrial process and the M. S. degrees from Federal Technological University of Parana (UTFPR-CP), Cornélio Procópio, Brazil, in 2009, 2010 and 2012, respectively. Since 2013, he has been with the Electrical Engineering Department of Federal Technological University of Paraná (UTFPR-PG), Ponta Grossa, PR, Brazil, where he is currently Professor of Electronic Engineering. His present research interest involves digital signal processing and applications, power quality, active power filters and photovoltaic systems. He is member of Brazilian Power Electronics Society.

Vinícius Dário Bacon was born in Arapongas, PR, Brazil, in 1991. He received the B.S. degree in electrical engineering from Federal Technological University of Paraná (UTFPRCP), Cornélio Procópio, PR, Brazil, in 2013. He is currently a student of the Master Science course in electrical engineering at Federal Technological University of Paraná (UTFPR-CP). His present researches involve power quality, active power filters, renewable and alternative energy sources, digital signal processing and applications, and UPS systems.

Leonardo Poltronieri Sampaio was born in São José do Rio Preto, SP, Brazil, in 1983. He received the B. S., M.S. and $\mathrm{Ph}$.D. degrees all in electrical engineering from São Paulo State University (UNESP), Ilha Solteira, SP, Brazil, in 2008, 2010 and 2013, respectively. Since 2012, he has been with the Electrical Engineering Department of Federal Technological University of Paraná (UTFPR-CP), Cornélio Procópio, PR, Brazil, where he is currently Professor of Electrical Engineering. His present research involves computer programming, education in power electronics, education tools, dc-dc converters, inverters, renewable and alternative energy sources, photovoltaic systems, power electronic converters. He is member of Brazilian Power Electronics Society. 